Tomasz Kornecki

Uniwersytet Papieski Jana Pawła II w Krakowie

\title{
Wybrane aspekty dobra rodziny oraz ochrony praw dziecka na podstawie przepisów Konstytucji Rzeczypospolitej Polskiej z 2 kwietnia 1997 roku oraz nauczania Jana Pawła II skierowanego do rodaków w czasie pielgrzymek do Polski
}

W nauczaniu Jana Pawła II miejsce rodziny oraz dziecka było wyjątkowe. Papież dostrzegał wartość najmniejszej komórki społecznej i wskazywał, w jaki sposób powinno być chronione dziecko oraz jak zapewnić dobro rodzinie, narażonej we współczesnym świecie na wiele różnorakich niebezpieczeństw. Dziecko jest kształtowane w różny sposób, ogólnie nazywamy to kształtowanie wychowaniem, w którym uczestniczy wiele podmiotów ${ }^{1}$, a wpływ na rodzinę mają takie wymiary ludzkiego życia, jak ekonomika, media czy prawo. Człowiek funkcjonuje bowiem w odpowiedniej rzeczywistości ekonomicznej - inaczej wyglądającej w krajach zachodnich inaczej w pań-

Por. W. Pomykało, Wychowanie, [w:] Encyklopedia pedagogiczna, Warszawa 1997, s. 916-917. 
stwach postkomunistycznych, takich jak Polska. Podobnie jest ze światem mediów czy też systemem prawnym.

Wydaje się zatem słuszne podjęcie próby „zestawienia”, lecz nie porównania tego, co Ojciec Święty mówił na temat ochrony rodziny oraz zapewnienia dobra dziecka do Polaków jako swoich rodaków, z tym, co na ten temat stanowi najwyższy akt prawny obowiązujący na terenie Rzeczypospolitej Polskiej, czyli Konstytucja z 2 kwietnia 1997 roku. Rodzina bowiem jako zjawisko socjologiczne jest również przedmiotem, którym interesuje się prawo ${ }^{2}$. Ważne jest, by papieskie nauczanie przekładało się na życie społeczne, w tym na prawo stanowione, wypływające z prawa naturalnego, jakie przynależy każdej osobie ludzkiej.

Poniższy artykuł przedstawia wybrane przez autora przesłanie Jana Pawła II dotyczące dziecka oraz rodziny, a także ukazuje, w jaki sposób do tych problemów odnosi się Konstytucja w artykułach 71 oraz 72.

Chcąc jednak pokazać nauczanie Papieża i przybliżyć przepisy ustawy zasadniczej, warto podjąć krótką charakterystykę wizyt Ojca Świętego do Ojczyzny. Odbywały się one bowiem w konkretnym kontekście politycznym i społecznym. Należy podkreślić, iż także poza Polską Jan Paweł II kierował do rodaków słowa o rodzinie oraz wartości dziecka, jednak ze względu na bogactwo nauczania nie zostaną w tym opracowaniu przybliżone.

\section{Charakterystyka pielgrzymek Jana Pawła II do Ojczyzny}

Papież Polak odbył łącznie 104 pielgrzymki, w tym aż osiem do Ojczyzny. Miały one miejsce w różnych okresach historycznych od PRL po III RP. Każda z wizyt przebiegała w innej atmosferze społecznej i politycznej.

Pierwsza z nich trwała od 2 do 10 czerwca 1979 roku3 $^{3}$. Był to okres całkowitego panowania komunizmu na terenie Polski. System był umocniony i nic nie wskazywało na jego rychłą zmianę. Państwo powstałe na zgliszczach II RP charakteryzowało się, podobnie jak obecnie, zerwaną ciagłością, brakiem odniesienia do najważniejszych dla Polaków wartości, totalitaryzmem niszczącym duchową jedność oraz świadomość jego mieszkańców ${ }^{4}$. Mimo

\footnotetext{
Por. J. Ignatowicz, Prawo rodzinne, Warszawa 1996, s. 12.

Por. T. Borutka, W życiu i w śmierci Totus Tuus, Kraków 2010, s. 116.

4 Por. R. Legutko, Esej o duszy polskiej, Kraków 2008, s. 7.
} 
tego, w czerwcu 1979 roku nastąpił przełom i owocem papieskiej wizyty było powstanie pierwszego w państwach komunistycznych niezależnego od władzy związku zawodowego „Solidarność”.

Kolejna pielgrzymka odbyła się w roku 1983 w dniach od 16 do 23 czerwca. Skutkiem tej wizyty było, między innymi, zawieszenie, wprowadzonego 13 maja 1981 roku stanu wojennego ${ }^{5}$. Warto zauważyć, że w tym czasie religijność Polaków była stosunkowo wysoka w skali innych narodów okupowanych przez Związek Sowiecki ${ }^{6}$, co widać na przykładach poszczególnych osób - religijność owa nie zawsze przekładała się na życie osobiste i nie zawsze była równie "gorliwa” 7 . Przed tą pielgrzymką, podobnie jak przed pozostałymi wizytami Ojca Świętego, Służba Bezpieczeństwa „wpadała w panikę”, gdyż Papież niejednokrotnie improwizował podczas swoich przemówień ${ }^{8}$, a jego słowa były tym samym trudne do przewidzenia.

Trzecia pielgrzymka do Polski miała miejsce w dniach 8 do 14 czerwca 1987 roku9. Sytuacja w kraju była coraz gorsza: „Solidarność” była rozbita, bunt przeciwko władzy podobnie jak w latach poprzednich pacyfikowany, a przeciętnemu mieszkańcowi PRL brakowało środków na podstawowe rzeczy niezbędne do życia.

Kolejna wizyta miała miejsce już w III Rzeczpospolitej. Zmiany ustrojowe doprowadziły do sytuacji, w której zaczęto budować kapitalizm, daleki jednak od praw równości i szacunku wobec innych. Papież przestrzegał przed nadmiernym zachłyśnięciem się wolnością. Odwiedził wówczas Polskę dwa razy: w dniach od 1 do 9 czerwca oraz od 13 do 16 sierpnia. Jednak ta druga wizyta stanowiła spotkanie z młodzieżą w ramach VI Światowego Dnia Młodzieży, który odbywał się w Częstochowie ${ }^{10}$.

22 maja 1995 roku Papież po raz kolejny przyjechał do swojej Ojczyzny. Wówczas pielgrzymka odbywała się pod hasłem "Zło dobrem zwyciężaj” ${ }^{11}$, które przyświecało życiu bł. ks. Jerzego Popiełuszki. Co ciekawe, tak jak

\footnotetext{
$5 \quad$ Por. T. Borutka, W życiu i śmierci Totus Tuus, dz. cyt., s. 117.

6 Por. T. Nowak, Zanim powstała „Solidarnośc”, Lublin 2005, s. 75.

7 Por. R. Boyes, Nagi prezydent. Życie polityczne Lecha Watesy, Londyn 1995, s. 31-32.

8 Por. P. Zyzak, Lech Watęsa. Idea i historia, Kraków 2011, s. 745.

9 Por. T. Borutka, W życiu i śmierci Totus Tuus, dz. cyt., s. 118.

Io Por. tamże, s. 119-120.

II Por. tamże, s. 120.
} 
w czasach PRL, w 1995 roku, tak obecnie nie udało się skazać osób bezpośrednio odpowiedzialnych za mord na kapelanie „Solidarności”"

Dwa lata później, w dniach od 31 maja do 10 czerwca Papież ponownie przyjechał do Polski ${ }^{13}$. To kraj, który nadal, mimo upływu ośmiu lat od tak zwanego przewrotu, nie posiadał uregulowanych stosunków ze Stolicą Apostolską, na której zasiadał Polak. Brzemię systemu komunistycznego widoczne było aż nadto.

W roku 1999 Ojciec Święty podczas swojej pielgrzymki (5-17 czerwca) rozważał Osiem błogosławieństw ${ }^{14}$. Sytuacja gospodarcza nadal nie była ustabilizowana, mimo upływu czasu Polacy odczuwali silne pozostałości PRL.

Korupcja, bezrobocie, trudne warunki pracy istniały także podczas kolejnej, ostatniej wizyty w Ojczyźnie, jaka miała miejsce w od 16 do 19 sierpnia 2002 roku. Ojciec Święty pozostawił wtedy swoisty testament spisany jego śladami i nauczaniem w Małopolsce.

Papieskie pielgrzymki zawsze towarzyszyły Polakom w ważnych, co nie znaczy łatwych dla nich chwilach. Papież, mimo iż był odpowiedzialny za cały Kościół powszechny, pozostał do końca Polakiem i sprawy jego Ojczyzny były mu niezwykle bliskie. Także te związane z rodziną i dzieckiem jako Bożym darem. Chcąc je przybliżyć, najpierw należy pochylić się nad tym, jakie są przepisy najwyższego aktu prawnego obowiązującego na terenie Rzeczypospolitej Polskiej dotyczące wspomnianych kwestii.

\section{Dobro rodziny w przepisach Konstytucji RP (art. 71)}

Konstytucja Rzeczypospolitej Polskiej z 2 kwietnia 1997 roku reguluje kwestie związane z dobrem rodziny, między innymi w artykule 71 zawartym w części zatytułowanej „Wolności i prawa ekonomiczne, socjalne i kulturalne” ${ }^{15}$. Przywołany przepis stanowi, iż „państwo w swojej polityce społecznej i gospodarczej uwzględnia dobro rodziny”" ${ }^{16}$. Widać zatem powiązanie

\footnotetext{
I2 Por. W. Sumliński, $Z$ mocy bezprawia, Warszawa 2011, s. 205.

s3 Por. T. Borutka, W życiu i śmierci Totus Tuus, dz. cyt., s. 121.

I4 Por. tamże, s. 122-123.

is Por. Konstytucja Rzeczypospolitej Polskiej z 2 kwietnia 1997 (Dz.U. Nr 78, poz. 483, z późn. zm.), art. 71 [dalej: KRP].

i6 Por. tamże.
} 
zarówno gospodarki, jak i polityki społecznej z rodziną. Elementy te bowiem wpływają na rozwój bądź degradację rodziny. Istotnym elementem jest rodzaj, w jaki prowadzone jest życie polityczne oraz to, na jakich podstawach opiera się gospodarka. Może ona bowiem być gospodarką skierowaną przeciwko rodzinie, podobnie jak polityka mająca w tym kontekście dwa wymiary: prorodzinny bądź antyrodzinny.

Należy podjąć próbę zdefiniowania tego, czym jest dobro rodziny. To przede wszystkim zapewnienie jej możliwości odpowiedniego funkcjonowania, począwszy od szans zarobkowych rodziców jak i szans mieszkaniowych. Jedynie wówczas gdy szanowane są prawa rodziny, co za tym idzie jej dobro, może mieć miejsce odpowiedni jej rozwój ${ }^{17}$. Rodzina bowiem nie jest oddzielona, niejako rozgraniczona i odseparowana od życia narodu i narodów, wręcz odwrotnie - funkcjonowanie rodziny wpływa na życie narodu, a to, w jaki sposób istnieje naród, ma wpływ na życie rodziny.

Jeżeli chodzi o kwestie gospodarcze, niewątpliwie na pierwszy plan wysuwa się możliwość uzyskania pracy, otrzymania odpowiedniego wynagrodzenia, jak również godnych warunków pracy. Stąd też prawo reguluje stosunek pracy na zasadzie umowy cywilnoprawnej, w tym także umów układów zbiorowych ${ }^{18}$, które mają chronić pracowników. Dzisiaj jednak, szczególnie na obszarze państw postkomunistycznych, prawa pracownika są niejednokrotnie łamane. Począwszy od zbyt niskich pensji, a skończywszy na zatrudnieniu „na czarno”, co nie daje żadnych ubezpieczeń osobie wykonującej pracę, a tym samym wpływa destabilizująco na rodzinę. Odnosząc się do polityki społecznej, warto zwrócić uwagę na kilka jej charakterystycznych cech, takich jak opieka zdrowotna, dostęp do źródeł kultury czy ubezpieczenia społeczne, które są traktowane niekiedy jako mające charakter cywilnoprawny ${ }^{19}$. Uwzględnienie polityki społecznej i gospodarczej w kontekście dobra rodziny powinno przede wszystkim brać pod uwagę sprawę elementarną, czyli szanse na założenie rodziny, następnie jej rozwój i odpowiednie, czyli godne jej funkcjonowanie.

\footnotetext{
${ }_{17}$ Por. Papieska Rada ds. Rodziny, Etyczny i pastoralny wymiar przemian demograficznych, Łomianki 1997, s. 20.

I8 Por. W. Szubert, Uktady zbiorowe pracy, Warszawa 1960, s. 8-15.

19 Por. K. Kolasiński, Charakter prawny sporów z zakresu ubezpieczenia spotecznego, Toruń 1974 , s. 117.
} 
Konstytucja stanowi, że rodziny, które znajdują się w trudnej sytuacji materialnej, a także społecznej, w tym w szczególny sposób rodziny wielodzietne oraz niepełne, posiadają prawo do „szczególnej” - jak to ujmuje ustawa zasadnicza - pomocy władz publicznych ${ }^{20}$. A zatem jednym z obowiązków państwa jest świadczenie pomocy rodzinom. Waga tego obowiązku jest tym bardziej istotna, że została zapisana w najważniejszym akcie prawnym. Nacisk związany z pomocą położony jest na rodziny wielodzietne oraz niepełne. Ustawodawca w ten sposób zobowiązał państwo do udzielania pomocy, jak założył, osobom, które mogą mieć problemy finansowe, bądź też osobom, które potrzebują różnego rodzaju wsparcia ze względu na większą liczbę dzieci. Na przykład na stronach internetowych lokalnych przewoźników miejskich znaleźć można informacje dotyczące zniżkowych cen biletów rodzinnych ${ }^{21}$. Nie jest to jednak sytuacja wyjątkowa, gdyż płacenie podatków ma na celu między innymi pomoc potrzebującym, bądź też wspomaganie, tak jak w tym przypadku, rodzin wielodzietnych. Każde finansowe wsparcie takich rodzin bądź rodzin niepełnych pochodzi właśnie z podatków. Ważne, by pieniądze te były wykorzystywane w odpowiedni sposób, właściwy dla wsparcia, a także dla ochrony praw dziecka, które to prawa przysługują każdej osobie ludzkiej.

\section{Ochrona praw dziecka w przepisach Konstytucji RP (art. 72)}

Dzieci stanowią niezwykłą wartość zarówno dla rodziny, jak i dla wspólnoty ludzi. Są gwarantem przetrwania biologicznego danego narodu. Stąd też polityka związana jest ze sferą wartości i idei ${ }^{22}$ także w odniesieniu do ochrony praw dziecka. W zależności od tego, jakie wartości będą przyjęte przez rządzących polityków, takie będzie podejście do dziecka i jego praw. Istotne jest, aby były one odpowiednio rozumiane i nie naruszały praw rodziców do wychowania swoich dzieci zgodnie z przekonaniami, w tym także religijnymi,

\footnotetext{
20 Por. KRP, art. 71.

${ }_{21}$ Por. http://www.mpk.krakow.pl/pl/bilety2/cenniki-biletow-jedno-i-wieloprzejazdowych/ (11.03.2013).

22 Por. P. Dobrowolski, S. Wróbel, Wprowadzenie do nauki o polityce, Katowice 1987, s. $51-52$.
} 
do czego mają prawo na przykład rodzice chrześcijańscy, by wychowywać dzieci „według zasad pedagogiki Chrystusowej”23. Państwo nie może przekraczać granic, jakie istnieją między jego działaniem a aktywnością rodziny. Każde przekroczenie tych granic jest naruszeniem dobra dziecka.

Konstytucja stanowi, iż Rzeczpospolita chroni prawa dziecka ${ }^{24}$, które mają szeroki zakres. Od prawa do życia, do wychowania, po prawa twórczego rozwoju własnej osoby. Dzieci bowiem charakteryzują się kreatywnością w swoim zachowaniu, gestach, ale i wypowiedziach ${ }^{25}$. Są twórcze, patrzą na świat inaczej niż osoby dorosłe, więcej dostrzegają. Mówiąc o prawach osoby ludzkiej, warto zwrócić uwagę na to, iż istotną kwestią jest uznanie płodu dziecka za osobę ${ }^{26}$. Pociąga to za sobą odpowiednie skutki prawne, a tym samym jest uszanowaniem praw dziecka. Jednak należy podkreślić, że dziecko poczęte od samego początku, a nie od momentu urodzenia, winno być uznane za człowieka. W ten sposób istnieje możliwość realizacji najważniejszego prawa, jakim jest prawo do życia osoby ludzkiej. Polskie prawo, poza Konstytucją, reguluje kwestie praw dziecka ${ }^{27} \mathrm{w}$ innych aktach prawnych.

Ustawa zasadnicza stanowi, iż „dziecko pozbawione opieki rodzicielskiej ma prawo do opieki i pomocy władz publicznych" ${ }^{28}$. Przepis ten jest istotną regulacją mającą na celu ochronę dzieci, które pozostałyby bez opieki rodzicielskiej. Jednak może zdarzyć się tak, że rodzice zostaną pozbawieni władzy rodzicielskiej niesłusznie, bądź też zostaną im odebrane dzieci, co w Polsce ma miejsce. Przypadki takie świadczą o złym funkcjonowaniu prawa oraz zbyt szerokich kompetencjach urzędników i braku odpowiedniej kontroli nad nimi. Zarówno organy władzy publicznej, jak również osoby odpowiedzialne za dziecko mają obowiązek wysłuchać oraz jeżeli jest to możliwe, wziąć pod uwagę zdanie dziecka ${ }^{29}$. Dzięki temu można uwzględnić jego indywidualne potrzeby oraz spojrzeć na to, co jest dla danego dziecka

\footnotetext{
${ }_{23}$ P. Poręba, Wspótżycie pokoleń na bazie rodzinnej, Olsztyn 1981, s. 47-48.

24 KRP, art. 72.1.

25 Por. R. Gloton, C. Clero, Twórcza aktywność dziecka, Warszawa 1976, s. 54.

26 Por. K. Kolańczyk, Prawo rzymskie, Warszawa 1999, s. 177.

27 Por. J. Bińczycka, Prawa dziecka - deklaracja i rzeczywistość, Kraków 1999, s. 57.

$28 \mathrm{KRP}$, art. 72.2.

$29 \mathrm{KRP}$, art. 72.3.
} 
istotne. Ważne jest zatem podejście personalistyczne, a co z tym jest związane -przede wszystkim uwzględnienie dobra każdego dziecka, niezależnie od pochodzenia. Oczywiście należy brać tutaj pod uwagę wiek dziecka i jego zdolność postrzegania świata ${ }^{30}$.

Konstytucja RP, w ramach ochrony praw dziecka, odwołuje się do ustawy określającej kompetencje oraz metodę powołania Rzecznika Praw Dziecka ${ }^{31}$. To jednak inny temat badań, który jest związany bezpośrednio ze wspomnianą instytucją. W tym miejscu, mając obraz przepisów Konstytucji odnoszących się do dobra rodziny oraz praw dziecka, warto zatrzymać się nad tym, co na ten temat mówił Jan Paweł II.

\section{Dobro rodziny w przesłaniu Jana Pawła II do rodaków}

Papież Jan Paweł II, dostrzegając wartość rodziny, „wychodził” w swoim przesłaniu do rodaków od relacji tej najmniejszej komórki społecznej do rzeczywistości otaczającej człowieka. Już podczas swojej pierwszej pielgrzymki powiedział, że „rodzina jest fundamentem życia ludzkiego w każdym wymiarze" $^{32}$. To ona bowiem stanowi podstawę istnienia człowieka i jego spotkania ze światem zewnętrznym. W rodzinie osoba ludzka uczy się elementarnych wartości oraz czerpie z niej wzorce zachowań. Można mówić o tym, że w rodzinie panuje dialog opieki oraz dialog dawania ${ }^{33}$. To właśnie w rodzinie dochodzi do budowania relacji międzyludzkich, które powinny być oparte na otwarciu się na drugą osobę.

Ojciec Święty wezwał rodaków, by modlili się z nim o jedność polskich rodzin $^{34}$. Jedność, która buduje stosunki między poszczególnymi osobami. Chcąc mówić o dobru rodziny, należy zauważyć, że swoje korzenie oparte

30 Por. J. Piaget, Narodziny inteligencji dziecka, Warszawa 1966, s. 4.

${ }_{31}$ Por. KRP, art. 72.4.

32 Jan Paweł II, Homilia podczas Mszy św. odprawionej pod Szczytem Jasnej Góry, Częstochowa, 4 VI 1979, [w:] tenże, Pielgrzymki do Ojczyzny. Przemówienia. Homilie, Kraków 2006, s. 62.

33 Por. T. Kukułowicz, Rodzina wychowuje, „Ateneum Kapłańskie”, 1975, t. 84, z. 1, s. $82-83$.

34 Jan Paweł II, Homilia w czasie Mszy św. odprawionej pod Szczytem Jasnej Góry dla pielgrzymów z Dolnego Ślaska i Ślaska Opolskiego, [w:] tenże, Pielgrzymki do Ojczyzny, dz. cyt., s. 105 . 
na jedności ma ono w miłości, wzajemnym zaufaniu, a także w samym sakramencie małżeństwa, który stanowi początek komunii w rodzinie, komunii rozumianej jako jedność. Komunii, która powinna być wzorem współżycia między ludźmi ${ }^{35}$. Jak podkreślał Jan Paweł II, duchowa więź stanowi najsilniejszy fundament jedności ${ }^{36}$, a zatem w rodzinie na pierwszym planie powinien być wymiar duchowy relacji między jej członkami. Wartość ta winna być chroniona przez państwo. Naruszeniem jedności rodziny jest stworzenie ekonomicznego przymusu do emigracji zarobkowej. W takiej sytuacji rodzinna jedność zagrożona jest przez zdrady czy też rozpad małżeństwa.

Jan Paweł II prosił o modlitwę, aby rodzina była ostoją takich wartości, jak sprawiedliwość oraz miłość ${ }^{37}$. Sprawiedliwość stanowi zasadę, która zobowiązuje osobę ludzką do tego, by respektowała prawa innych zarówno w relacji do osób, jak i do rzeczy, a zatem sprawiedliwość to oddanie tego, co się komuś innemu należy ${ }^{38}$. Definicja sprawiedliwości związana jest z tą wartością, która stanowi troskę o dobro drugiego człowieka, czyli z miłością. Miłość bowiem to nie tylko uczucie w relacjach rodzinnych, ale o wiele głębsze zaangażowanie jednej osoby w życie drugiej. Sprawiedliwość oraz miłość uzupełniają się nawzajem, dopełniają i powinny się przenikać. Bez wartości, takich jak sprawiedliwość oraz miłość, nie sposób mówić o dobru rodziny. Rodzina oparta na nienawiści i braku sprawiedliwości jest głęboko zraniona. Rodzina, jak nauczał Jan Paweł II, jest podstawową szkołą, w której człowiek uczy się społecznej miłości ${ }^{39}$.

Dobro rodziny związane jest także z odpowiednim statusem materialnym. Ojciec Święty podkreślił, iż: „Racja bytu rodziny jest jednym z podstawowych wyznaczników ekonomii i polityki pracy. Wówczas zachowują one swoją właściwość etyczną, jeśli liczą się z potrzebami rodziny, z prawami rodziny. Poprzez pracę dorosły mężczyzna powinien zdobyć środki potrzebne

35 Por. P. Poręba, Wspótżycie pokoleń na bazie rodzinnej, Olsztyn 1981, s. 122.

${ }_{36}$ Por. Jan Paweł II, Homilia w czasie Mszy św. odprawionej pod Szczytem Jasnej Góry dla pielgrzymów z Dolnego Śląska i Śląka Opolskiego, dz. cyt., s. 105.

37 Por. tenże, Apel Jasnogórski, Częstochowa, 5 VI 1979, [w:] tenże, Pielgrzymki do Ojczyzny, dz. cyt., s. 110.

${ }_{38}$ Por. J. Kalniuk, Sprawiedliwość, [w:] Encyklopedia nauczania społecznego Jana Pawta II, red. A. Zwoliński, Radom 2003, s. 482.

39 Por. Jan Paweł II, Homilia w czasie nabożeństwa maryjnego odprawionego na lotnisku w Muchowcu, Katowice, 20 VI 1983, [w:] tenże, Pielgrzymki do Ojczyzny, dz. cyt., s. 314. 
do utrzymania swojej rodziny. Macierzyństwo zaś w polityce i ekonomii pracy winno być traktowane jako wielki cel i wielkie zadanie samo dla siebie. Łączy się bowiem z nim inna, wielka praca, w której nikt matki rodzącej, karmiącej, wychowującej nie zastąpi. Nic też nie zastąpi serca matki w domu, serca, które zawsze tam jest, zawsze tam czeka. Prawdziwe poszanowanie pracy niesie z sobą należną cześć dla macierzyństwa, a nigdy inaczej. Od tego też zależy zdrowie moralne całego społeczeństwa" ${ }^{40}$. Widać zatem, że dobro rodziny powinno być szanowane ze względu na płeć rodziców, ich powołanie nie tylko do wychowania, ale również podejmowania pracy zawodowej. We współczesnej Polsce coraz więcej osób pracuje zawodowo kosztem budowania relacji rodzinnych.

Warto zwrócić uwagę na wartości, na jakie wskazał Jan Paweł II w Szczecinie 11 czerwca 1987 roku podczas Mszy św. dla rodzin. Dobro rodziny oparte jest, poza innymi elementami, na radości oraz rozrywce ${ }^{41}$. Papież zwrócił uwagę na cały wymiar dóbr kulturowych związanych z rodziną i jej prawidłowym funkcjonowaniem. Obecnie rodzina ulega wielu przemianom kulturowym ${ }^{42}$. Często nie służą one jej dobru, a wręcz są skierowane przeciwko niej. Przemiany te widać w sferze środków społecznego przekazu, w sferze podejścia do kwestii moralnych. Ojciec Święty wskazuje także na inne zagrożenia, jakim może zostać poddane dobro rodziny: „Za cyframi wszak, za analizami i opisami stoi tu zawsze żywy człowiek, tragedia jego serca, jego życia, tragedia jego powołania. Rozwody... wysoka liczba rozwodów. Trwałe skłócenie i konflikty w wielu rodzinach, a także długotrwałe rozstania na skutek wyjazdu jednego z małżonków za granicę. Prócz tego coraz częściej dochodzi też do zamykania się rodziny wyłącznie wokół własnych spraw, do jakiejś niezdolności otwarcia się na innych, na sprawy drugiego człowieka czy innej rodziny. Co więcej, zanika czasem prawdziwa więź wewnątrz samej rodziny: brakuje niekiedy głębszej miłości nawet między rodzicami i dziećmi czy też wśród rodzeństwa. A ileż rodzin choruje i cierpi

40 Tenże, Homilia w czasie Mszy św. odprawionej pod Szczytem Jasnej Góry dla pielgrzymów z Górnego Śląska i Zagłębia Dąbrowskiego, Częstochowa, 6 VI 1979, [w:] tenże, Pielgrzymki do Ojczyzny, dz. cyt., s. 135.

${ }_{4 \mathrm{I}}$ Por. tenże, Homilia w czasie Mszy św. odprawionej dla rodzin, Szczecin, 11 VI 1987, [w:] tenże, Pielgrzymki do Ojczyzny, dz. cyt., s. 452.

42 Por. T. Borutka, Nauczanie społeczne Jana Pawła II, Kraków 1994, s. 128. 
na skutek nadużywania alkoholu przez niektórych swoich członków” ${ }^{43}$. Słowa te padły u progu budowania III Rzeczpospolitej. Mimo upływu wielu lat są, jak się wydaje, coraz bardziej aktualne. Wyjazdy poza granice Polski w celach zarobkowych, alkoholizm, zanikanie więzi rodzinnych to te sprawy, które wpływają negatywnie na dobro rodziny. Stanowią istotne zagrożenie jej trwałości i stabilności, a także mogą narażać prawa dziecka. Należy zwrócić uwagę na to, co Ojciec Święty mówił na temat praw dziecka i ich ochrony.

\section{Ochrona praw dziecka w przesłaniu Jana Pawła II do rodaków}

Rodzina jest miejscem i wspólnotą, w której kształtuje się życie dziecka. Jako wspólnota osób powinna być ukierunkowana na dobro dziecka, a także na ochronę i poszanowanie jego praw. Te słowa odnoszą się także, a może lepiej powiedzieć przede wszystkim, do państwa, które winno zapewnić dziecku odpowiednią ochronę jego praw.

Pierwszym podstawowym prawem dziecka jest prawo do życia. W tym kontekście padły bardzo istotne słowa Ojca Świętego. Wypowiedział je w Kaliszu w 1997 roku. Słowa te to swoisty apel skierowany do Polaków. „Drodzy bracia i siostry, bądźcie solidarni z życiem. Wołanie to kieruję do wszystkich moich rodaków bez względu na przekonania religijne. Do wszystkich ludzi, nikogo nie wyłączając. $Z$ tego miejsca raz jeszcze powtarzam to, co powiedziałem w październiku ubiegłego roku: «naród, który zabija własne dzieci, staje się narodem bez przyszłości». Wierzcie mi, że nie było mi łatwo tego powiedzieć z myślą o moim narodzie. Bo ja pragnę dla niego przyszłości, wspaniałej przyszłości. Potrzebna jest przeto powszechna mobilizacja sumień i wspólny wysiłek etyczny, aby wprowadzić w czyn wielką strategię obrony życia. Dzisiaj świat stał się areną bitwy o życie. Trwa walka między cywilizacją życia a cywilizacją śmierci. Dlatego tak ważne jest budowanie «kultury życia»: tworzenie dzieł i wzorców kulturowych, które będą podkreślały wielkość i godność ludzkiego życia; zakładanie instytucji naukowych i oświatowych, które będą promowały prawdziwą wizję osoby ludzkiej, życia małżeńskiego

43 Jan Paweł II, Homilia w czasie Mszy św. odprawionej na lotnisku w Mastowie, Kielce, 3 VI 1991, [w:] tenże, Pielgrzymki do Ojczyzny, dz. cyt., s. 615-616. 
i rodzinnego; tworzenie środowisk wcielających w praktykę codziennego życia miłość miłosierną, którą Bóg obdarza każdego człowieka, zwłaszcza człowieka cierpiącego, słabego, ubogiego, nienarodzonego" ${ }^{44}$. Walka o godność i prawo do życia człowieka, szczególnie tego jeszcze nienarodzonego nadal trwa. Podejmowane są próby liberalizacji przepisów odnoszących się do wspomnianej kwestii.

Ojciec Święty Jan Paweł II wskazał także na prawo do wychowania. To jedno z podstawowych praw. $Z$ nim związane jest prawo do posiadania rodziny, które to prawo ma każde dziecko. To właśnie w rodzinie rozpoznaje ono miłość. Pierwszymi wychowawcami są rodzice, od których zależy stworzenie odpowiedniej rodzinnej atmosfery ${ }^{45}$. Żadna instytucja zastępcza nie jest w stanie dać domowego i rodzinnego ciepła dziecku ${ }^{46}$.

Kolejnym prawem dziecka jest możliwość uczestnictwa w życiu religijnym. Papież podkreślał, że dzieci szukają kontaktu z Jezusem. I to zarówno z Jezusem z okresu Jego dziecięctwa, jak i z Jezusem, który zbawia świat ${ }^{47}$. W tym kontekście można odnieść się do teologii duchowości, która zaczynając od doświadczenia chrześcijańskiego, dąży do teologicznej interpretacji ${ }^{48}$. Ojciec Święty nawiązuje do słów Zbawiciela: „Pozwólcie dzieciom przyjść do Mnie” (Mk 10, 14), które stanowią zaproszenie wynikające z miłości Chrystusa do dzieci i pragnienia, by były blisko Niego. Wielokrotnie dzieci otrzymywały błogosławieństwo od Jezusa, a nawet były stawiane osobom starszym za wzór, po to, by serca dorosłych stawały się dobre, ufne oraz przepełnione miłością ${ }^{49}$. Tym samym dzieci w jakimś sensie mogą stawać się wychowawcami osób dorosłych.

44 Tenże, Homilia w czasie Mszy św. odprawionej przed sanktuarium św. Józefa, Kalisz, 4 VI 1997, [w:] tenże, Pielgrzymki do Ojczyzny, dz. cyt., s. 925.

45 Por. tenże, Homilia w czasie Mszy św., Łowicz, 14 VI 1999, [w:] tenże, Pielgrzymki do Ojczyzny, dz. cyt., s. 1143.

46 Por. tenże, Homilia w czasie Mszy św. odprawionej dla rodzin, dz. cyt., s. 454.

47 Por. tenże, Przemówienie wygłoszone w szpitalu pediatrycznym, Olsztyn, 6 VI 1991, [w:] tenże, Pielgrzymki do Ojczyzny, dz. cyt., s. 660.

${ }_{48}$ Por. M. B. Borde, Liminaire, [w:] L'apport théologique de sainte Thérèse de l'Enfant-Jésus, docteur de l'Église, red. D. Chardonnens, Ph. Hugo,Toulouse 2000, s. 8.

49 Por. Jan Paweł II, Stowo do dzieci pierwszokomunijnych zgromadzonych $w$ kościele Świętej Rodziny, Zakopane, 7 VI 1997, [w:] tenże, Pielgrzymki do Ojczyzny, dz. cyt., s. 960 . 
Każde dziecko ma prawo do miłości oraz radości, których pragnie dla niego sam Bóg. Radość ma swoje źródło w samym okresie życia, jakim jest dzieciństwo. Dziecko potrzebuje miłości wyrażonej w uczuciu rodziców, w cieple, jakim je obdarowują, ale także w wymaganiach, jakie mu stawiają po to, by odpowiednio wprowadzić je w świat dorosłych. Zbyt szybkie dorastanie powoduje zabranie tej wartości dzieciństwa. Dorastanie to może być spowodowane względami politycznymi (przymusowe wcielanie dzieci do armii w niektórych częściach Afryki, praca dzieci, brak tematów tabu).

Warto, by powyższe prawa dziecka wymienione przez Ojca Świętego były postrzegane i chronione jednocześnie, przenikając tym samym i ubogacając rodziny.

\section{Zakończenie}

Rodzina to związek dwojga osób, których relacja zmierza, między innymi, do tego, by mieć potomstwo. Zdrowa rodzina to taka, w której mają miejsce odpowiednie relacje pomiędzy jej poszczególnymi członkami. Relacje budowane wewnątrz tej najmniejszej komórki społecznej, ale także relacje, na które wpływają czynniki zewnętrzne.

Jednym z takich zewnętrznych czynników jest prawo stanowione, gdzie wyróżnić można konstytucję. Polska ustawa zasadnicza w swoich przepisach chroni zarówno prawa dziecka, jak i dobro rodziny. Przepisy te, stanowiące podstawę innych aktów prawnych, powinny być w odpowiedni sposób przestrzegane, a także interpretowane. Rodzina oraz dziecko mają elementarne prawo do wolności i rozwoju, a także możliwości funkcjonowania na godnym poziomie ekonomicznym. Pomimo dwudziestu kilku lat od początku tak zwanych „zmian ustrojowych” w Polsce rodzina oraz dzieci zmagają się z coraz liczniejszymi problemami. Niewątpliwie źle funkcjonuje ustawodawstwo, wprowadzane są rozwiązania mające na celu degradację rodziny. $\mathrm{Z}$ drugiej strony pomijany jest, a nawet atakowany i wyśmiewany głos Kościoła dotyczący powyższych kwestii. W kraju, z którego pochodził Jan Paweł II, głos Papieża dotyczący rodziny i dzieci jest często skutecznie zagłuszany. A Ojciec Święty podkreślał, iż rodzina i dzieci należą do najważniejszych wartości wspólnoty ludzkiej. „Pośród [...] wielu dróg rodzina jest drogą pierwszą i z wielu względów najważniejszą. Jest drogą powszechną, pozostając za każdym razem drogą szczególną, jedyną i niepowtarzalną, tak 
jak niepowtarzalny jest każdy człowiek. Rodzina jest tą drogą, od której nie może on się odłączyć. Wszak normalnie każdy z nas w rodzinie przychodzi na świat, można więc powiedzieć, że rodzinie zawdzięcza sam fakt bycia człowiekiem. A jeśli w tym przyjściu na świat oraz we wchodzeniu w świat człowiekowi brakuje rodziny, to jest to zawsze wyłom i brak nad wyraz niepokojący i bolesny, który potem ciąży na całym życiu. Tak więc Kościół ogarnia swą macierzyńską troską wszystkich, którzy znajdują się w takich sytuacjach, ponieważ dobrze wie, że rodzina spełnia funkcję podstawową. Wie on ponadto, iż człowiek wychodzi z rodziny, aby z kolei w nowej rodzinie urzeczywistnić swe życiowe powołanie. Ale nawet kiedy wybiera życie w samotności - to i tutaj rodzina pozostaje wciąż jak gdyby jego egzystencjalnym horyzontem jako ta podstawowa wspólnota, na której opiera się całe życie społeczne człowieka w różnych wymiarach aż do najrozleglejszych" ${ }^{50}$.

Ochrona rodziny w papieskim nauczaniu ujęta jest w wielu różnych odsłonach. Współczesna Polska potrzebuje rodziny, bez niej bowiem nie może istnieć. Warto więc nie tylko wsłuchiwać się w głos Ojca Świętego, ale także zgłębiać jego nauczanie dotyczące rodziny i dziecka w Polsce w kolejnych opracowaniach naukowych.

so Tenże, List do Rodzin Gratissimam sane, Watykan 1994, nr 2. 


\section{Selected Aspects of Family Welfare and Protection of Child Rights Stipulated in the Constitution of the Republic of Poland of 2nd April, 1997 and Discussed in the Teaching of John Paul II Addressed to His Compatriots during the Pilgrimages to Poland}

Summary

The family is the union of two people whose relationship aims, among other things, at having children. The relationship built within the smallest cells of society, but also relationship affected by external factors. One of these external factors is the statutory law, including the constitution. The Polish Constitution with its regulations and principles protects the rights of both the child and family well-being. These rules, which form the basis of other legislative acts, should be respected and interpreted in the appropriate way. Pope John Paul II emphasized that family and children are the most important values for humanity. In papal teaching the protection of the family is discussed frequently and from many different angles. Modern Poland needs the family to exist. Hence one should not only listen to the voice of the Holy Father, but also explore the papal teachings on the family and children in Poland in subsequent research.

Kewords: family, child, constitution, John Paul II, Poland, Church teaching 
